\title{
Improving Law Student Ability on Legal Writing through Critical and Logical Thinking by IRAC Method
}

\author{
Ridwan Arifin ${ }^{*}$, Riska Alkadri ${ }^{2}$, Dewi Puspa Sari ${ }^{3}$, Lilies \\ Resthiningsih ${ }^{4}$, Amarru Muftie Holish ${ }^{5}$ \\ 1,2,5 Faculty of Law, Universitas Negeri Semarang, Indonesia \\ ${ }^{3,4}$ Law Library, Universitas Negeri Semarang, Indonesia \\ *Corresponding Author: R.Arifin, email: ridwan.arifin@mail.unnes.ac.id
}

Abstract: The lack of good stigma is attached to student activists, ranging from the unsatisfactory level of academic quality, graduating on time, not responsive and very reactive, hard and opposing views, to demonstrations that are colored by violence. The stigma is only in a few cases, not all activists face such conditions, but this stigma seems to have been far attached. The development of student activists today demands that activists must also have three literacy abilities: data literacy, humanitarian literacy, and technological literacy. However, based on the preliminary results of this activity, 90 percent of UNNES Law School student activists agreed that activists must have a critical attitude and critical writing skills, but only about 10 percent of activists who had taken it seriously (thought publications in various forms). This activity is aimed at developing the critical abilities of student activists through increased publications in various media. This activity also aims to establish a critical writing community for student activists and present a concrete forum for channeling ideas and solutions for student activists in writing that can be read by many people. This activity is carried out through a critical thinking approach in legal studies using the IRAC (Issue, Rule, Application, Conclusion) method which is commonly used in analyzing various cases in legal study thinking.

Keywords: student activists; critical thinking; publications; legal writing

\section{How to cite:}

Arifin, R. Alkadri, R., Sari, D.P., Resthiningsih, R., \& Holish, A.M. 'Improving Law Student Ability on Legal Writing through Critical and Logical Thinking by IRAC Method.' Indonesian Journal of Advocacy and Legal Services, 1(1), 107-128. DOI: 10.15294/ijals.v1i1.33706 


\section{A. Introduction}

The development of student activists is one of the issues that has been studied by many parties, especially related to the movement and its contribution to the progress of the nation. However, in addition to positive views towards student activists, so far there have also been developing negative stereotypes and stigma attached to student activists themselves related to academic achievement and their study period. Student activists are almost always associated with low academic performance and late graduation, or even drop out. High academic achievement and passing study on time for most students may also be for educators and education experts to be the two main standards of study success, but for activist students, the meaning of achievement is not just a high GPA or fast graduation (Anwar, 2012).

Students as agents of change and agents of social control are actually the mouthpiece of the people. Consequently, student assignments are not only studying and busy with assignments, but are also grounded in the community. This is in accordance with the Tri Dharma of Higher Education which implies aspects of education, research and community service. From this concept it can be clearly seen that the scope of students is study and society. However, sometimes student activists encounter obstacles in dividing time between academia and organizations (Barr \& Treasure, 2016).

Research of PiPi-Hoy, Jitendra, and Kern (2009) stated that the results of studies conducted show that self-reports or time management skills are often related to academic achievement. Lower management effectiveness creates stress and tension. A good time manager is planning and organization. In addition, inefficient use of time, lack of control over time demands and inadequate amount of time turned out to have a negative impact on the psychological individual.

Meanwhile, in the paradigm of a system of social change both in revolutionary and evolutionary values and structures, student activities are influenced by social movements from individual environments and social groups that are part of the individual self. Social movements can arise in a variety of interests, such as changing the structure of social relations, changing worldviews, and fighting over political roles (Susan, 2009; Septiani, 2016). This is also the case with some of the dynamics of student activists at the Faculty of Law, Semarang State University (FH UNNES). Social changes that exist in some cases trigger various conflicts, for example in the case of demonstrations in the campus environment in the refusal of 
the allowance (Anonymous, 2018; Sugiyarto, 2018; Budi, 2018; Widiarto, 2018).

According to Rollo May (1967) in Feist, J. \& Feist, G.J. (2010: 65), that humans who are involved in conflict and collisions between ideality and reality that occur will deny destiny, lose the reason to 'be' and have no direction. They walk without having a goal or target. Then they will engage in behavior that makes them lose and break. They feel insignificant in a world that is increasingly dehumanizing individuals. This insignificant feeling is what directs humans to apathy and a state of decreased consciousness.

Thus, according to Oley (2013), conflict tendencies are natural and very natural in the dynamics of student activists, however, responses and reactions to these conflicts are very important to be considered to reduce the negative impacts. One of them is by providing sufficient space and space for the development of democracy in the campus environment, including the development of students' critical attitudes.

Tawakal (2015) confirms the critical attitude that exists in students, in which he thinks that the critical attitude is raised because there is a deviation, and like a problem, there must be a solution. Critical attitude, according to him, is solutive, which does not only throw arguments without concrete solutions. Critical attitude is not to bring down opponents, but to build cohesiveness and togetherness. Critical is objective, as a student, the horizon of knowledge must be open to change and be sensitive and judge something that is not random, there must be concrete facts that support the argument and based on an objective view, not a subjective view that only benefits some groups. Critical attitude is real or real, not a fictitious thing that is deliberately raised and used as controversy, is non-existent and solution-oriented, not creating new problems. Even according to Wae (2014) as an agent of change, students should also be critical and face this situation. By being critical, student insights will increase. Their character will also be formed into a wise person handling the problem. One of the ways is by utilizing the freedom to express thoughts as regulated in the 1945 Constitution Article 28E paragraph 2. Certainly by paying attention to ethics and using polite sentences.

Thus, channeling critical student attitudes must be directed to maximize student potential. This activity is expected to be able to provide solutions to partner problems (UNNES Faculty of Law Student Activists) in building critical attitudes through the development of ongoing publications.

The problems faced by partners, based on the results of a preliminary survey (of 55 UNHES FH student activists, May-April 2019), showed 63.6\% 
(35) agreed that the ability of a critical attitude for student activity was needed for personal capacity building, however, the survey results also showed that $52.7 \%$ (29) agreed that studies and discussions conducted by student activists only ended in discussion forums without further action. In fact, the results of discussions and student studies are important as a solution to the problems faced by the community, so that in practice, many solutions presented by student activists are not able to be transferred to a more concrete form towards the community. In fact, the critical level and publication of student activist thoughts, only 9.1\% (5) have ever published their thoughts, and 90.9\% (50) have never been at all. Therefore, the program to increase publicity as a place for channeling critical attitudes for UNNES Law Faculty student activists is very important.

The case studied was the condition of student activists in the Faculty of Law UNNES where in a preliminary study conducted by the author proved that the level of publication and literacy of student activists was at $1.8 \%$ (out of a total of 55 student activists surveyed). However, the level of discussion and forum for student activist studies was quite high, at around $76.4 \%$.

\section{B. Method}

This research and program uses several methods and approaches. To search for preliminary data, this study uses interviews and observations with media media. Preliminary research conducted a survey of 55 student activists within the Faculty of Law UNNES. This program involves student activists in a number of stages. The program is conducted intensively with clear output targets, namely the publication of the results of students' critical thinking in the field of law in the form of scientific articles or books, or other publications.

The stages carried out in this research and service program are as follows.

\section{Preliminary Activities}

The implementation of this service activity begins with a preliminary activity, where in this stage, the Implementation Team identifies deeper and further about the problems faced by partners and the solutions that can be offered. The identification of problems in this stage is done through the method of observation and questionnaire survey of the participants in the activity. 


\section{Activity Method}

Activities in this service are carried out with the following methods, namely:

1) Workshop and Training

This activity is carried out to get more tangible results and clear outcomes, so that workshops and training are conducted regularly and continuously. The workshop and training involved several parties, including the Implementation Team, Expert Team, Facilitator, and Participants.

2) Simulation and Application

Simulations are carried out to provide experience to partners through direct application related to critical thinking and critical writing. Participants will be introduced to various media for the distribution of opinions and critical writing both locally and nationally.

3) Publication

This method is carried out at the final stage, where the output of this activity is the scientific publication of critical thinking of UNNES Law Faculty students in several well-known publishing media, such as:

\begin{tabular}{lll}
\hline Publisher & Level & City of Publisher \\
\hline BPFH UNNES & National & Semarang \\
UNNES Press & National & Semarang \\
Thafa Media & National & Yogyakarta \\
SAGA Publication & National & Surabaya \\
\hline
\end{tabular}

In addition to publishing writings through these publishers, this activity also encourages student activists to publish scientific articles on critical thinking about legal science, legal thinking, legal case studies, and legal studies in several national journals as follows:

\begin{tabular}{lll}
\hline Name of Journal & Publisher & $\begin{array}{l}\text { City of } \\
\text { Publisher }\end{array}$ \\
\hline Cita Hukum & UIN Syarif Hidayatullah & Jakarta \\
\hline Ajudikasi & Universitas Serang Raya & Serang Banten \\
\hline Jambe Law Journal & Universitas Jambi & Jambi \\
\hline Jambura Law Review & $\begin{array}{l}\text { Universitas Negeri } \\
\text { Gorontalo }\end{array}$ & Gorontalo \\
\hline $\begin{array}{l}\text { Lex Scientia Law } \\
\text { Review }\end{array}$ & $\begin{array}{l}\text { Universitas Negeri } \\
\text { Semarang }\end{array}$ & Semarang \\
\hline Diversi & Universitas Islam Kadiri & Kediri \\
\hline $\begin{array}{l}\text { Gorontalo Law } \\
\text { Review }\end{array}$ & Universitas Gorontalo & Gorontalo \\
\hline Hukum dan & Universitas Semarang & Semarang \\
\hline
\end{tabular}




\begin{tabular}{lll}
\hline Masyarakat Madani & & \\
\hline $\begin{array}{l}\text { Halu Oleo Law } \\
\text { Review }\end{array}$ & Universitas Halu Oleo & Kendari \\
\hline Awang Long Law & STIH Awang Long & Samarinda \\
Review & & \\
\hline $\begin{array}{l}\text { Indonesian Journal of } \\
\text { Legal and Forensic }\end{array}$ & Universitas Udayana & Denpasar, Bali \\
Sciences & & \\
\hline $\begin{array}{l}\text { Indonesian Journal of } \\
\text { Disability Studies }\end{array}$ & Universitas Brawijaya & Malang \\
Assistance & &
\end{tabular}

The mentoring method is carried out to oversee and accompany partner participants periodically in achieving the expected output targets. Assistance is carried out concretely and applicatively, where partner participants will be assisted intensively and directly to resolve the problems encountered.

5) Case Study

Case study methods are provided to participants as a stimulus for logical, structured, and critical thinking paths to various problems in legal studies. The case studies offered vary according to the needs of the partner participants.

\section{Result and Discussion}

1. Introduction to Academic Writing and Critical Thinking

Wigati's research (2014) revealed that in practice in class students often complain that writing assignments are still considered very difficult to do. Writing turns out to be a scourge for students. In fact, mastery of the material is the basic goal of the teaching and learning process. Mastery of the material is also often used as the main consideration for measuring the success or failure of a teaching lecturer. In fact, in a class with students who have different writing, speaking, and analyzing abilities, it will cause difficulties to measure whether students are at the same intensity in their understanding. Students with high levels of competence will feel burdened because they have to wait for other friends to be able to understand the material and be able to apply it. As for students with low levels of competence, they will feel frustrated because they are not able to understand and do assignments easily. This gap will be evident in skillsbased courses. This is actually natural because in Krashen's theory (1984) understanding of language has the formula $\mathrm{N}+1$ which means that a 
person will not be able to understand higher matter before he understands correctly about the underlying material.

Fox (1993) defines writing as an activity expressing ideas, feelings, and opinions to communicate messages from the mind to written form. Writing has two steps in the process of displaying the meaning of ideas and conveying them in the form of written language. Through writing we can share ideas, apply feelings, and convince others.

Meanwhile, regarding the difficulty in writing (writing), Byrne (1988) categorizes three problems that make writing skills difficult to master, namely linguistic, cognitive, and content problems. The first problem is the aspect of language or linguistics. This relates to one's shrewdness in writing the correct structure and hence the sentences that are formed will be able to blend with one another. The result is that the text that is created can be well replicated by the reader. The second problem is cognitive problems related to one's mastery of the forms of language, structure, grammar and spelling that are useful for effective communication in writing. Harmer (2004) termed it with organizational problems which are certainly more complicated than organizational problems in speaking. The third is the problem of ideas. This relates to anything that someone can pour in his writing. Often someone loses ideas in the middle of the writing process.

Based on the problems that have been identified in relation to the academic writing capacity of student activists as described previously, to overcome these problems an introduction to academic writing and critical thinking is conducted for student activists within the Faculty of Law, Semarang State University. This initial introduction was held on Monday, June 10, 2019 at the Faculty of Law, Semarang State University.

At this stage, the activities were carried out with the method of socialization and lectures on academic writing and critical thinking. In this activity also explained the difference between academic writing and creative writing, as explained in table 4 below. Table 4 becomes the foundation of understanding for the beginning of this program for law student activists in writing scientific papers related to the field of law studies.

Table 4 Differences in Academic Writing and Creative Writing

\begin{tabular}{cll}
\hline No & Academic Writing & Creative Writing \\
\hline 1 & Non-fiction & Fiction \\
2 & Based on facts (pure facts) & Based on imagination (can also \\
& & be added by facts) \\
3 & For academic purposes & For literary or pop / \\
& & entertainment purposes
\end{tabular}




\begin{tabular}{|c|c|c|}
\hline & & (market orientation) \\
\hline 4 & Supported research (to obtain data) & $\begin{array}{l}\text { It could be supported by } \\
\text { research or not }\end{array}$ \\
\hline 5 & Supported references / literature & $\begin{array}{l}\text { It can be supported by } \\
\text { references or not }\end{array}$ \\
\hline 6 & Written in formal / academic & Written in a literary or pop \\
\hline & language & $\begin{array}{l}\text { language that is easily } \\
\text { understood by the public }\end{array}$ \\
\hline 7 & Use academic terms & Can use academic terms or not \\
\hline 8 & Comes with footnotes & $\begin{array}{l}\text { It can also not (depending on } \\
\text { the theme) }\end{array}$ \\
\hline 9 & Equipped with a reference list & $\begin{array}{l}\text { Not equipped with a reference } \\
\text { list }\end{array}$ \\
\hline 10 & $\begin{array}{l}\text { Use appendix or attachments (as } \\
\text { needed) }\end{array}$ & Not appendixing \\
\hline 11 & Using index (as needed) & There is no index \\
\hline
\end{tabular}

Source: Pranoto, 2010.

Meanwhile, furthermore, the introduction of the concept of academic writing refers to the stages of academic writing itself, which include: prewriting, organizing, drafting, editing, revising, and evaluating (Lestari \& Chasanatun, 2016). At the prewriting stage, participants of law student activists were asked to look for ideas, initial information material, and preparation for writing. The preparation of writing includes an introduction to the intended scientific journals, the selection of titles, frameworks of thought, and the composition of the writing arrangements.

The documentation of the activities at this stage can be seen from the following pictures.

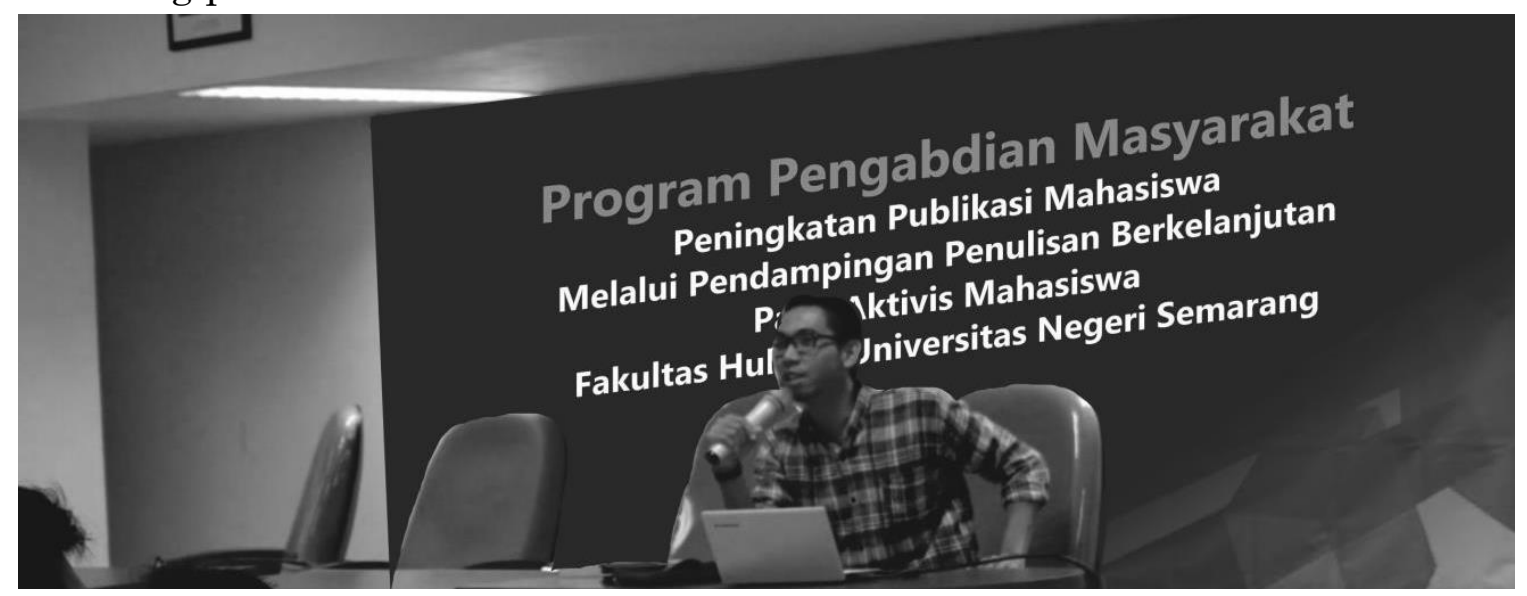

Figure 1. Presentation of Introduction to Academic Writing for Student Activists. Source: Personal Documentation, June 2019. 


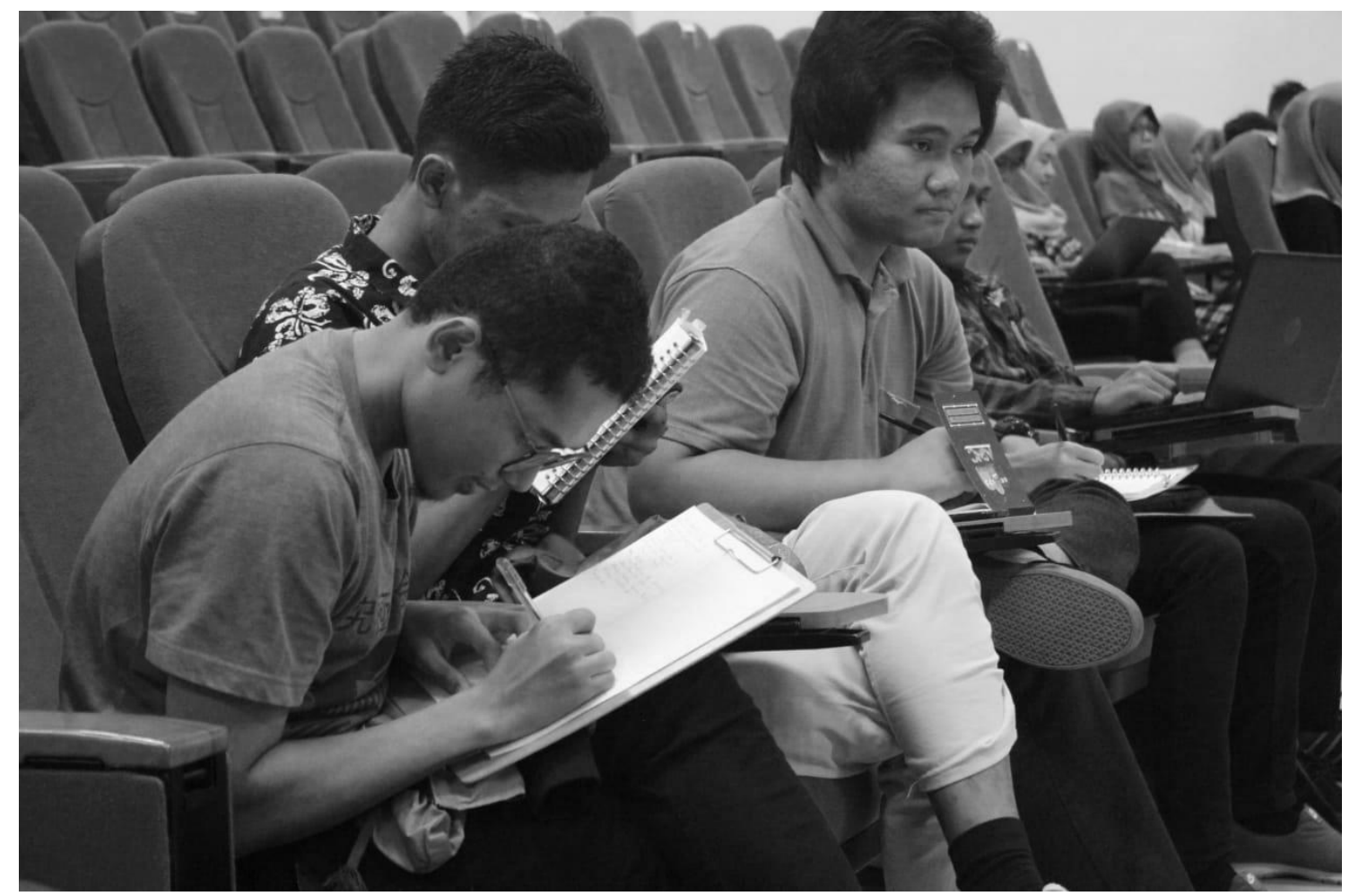

Figure 2. Participants of Community Service Program Activities. Source: Personal Documentation, June 2019.
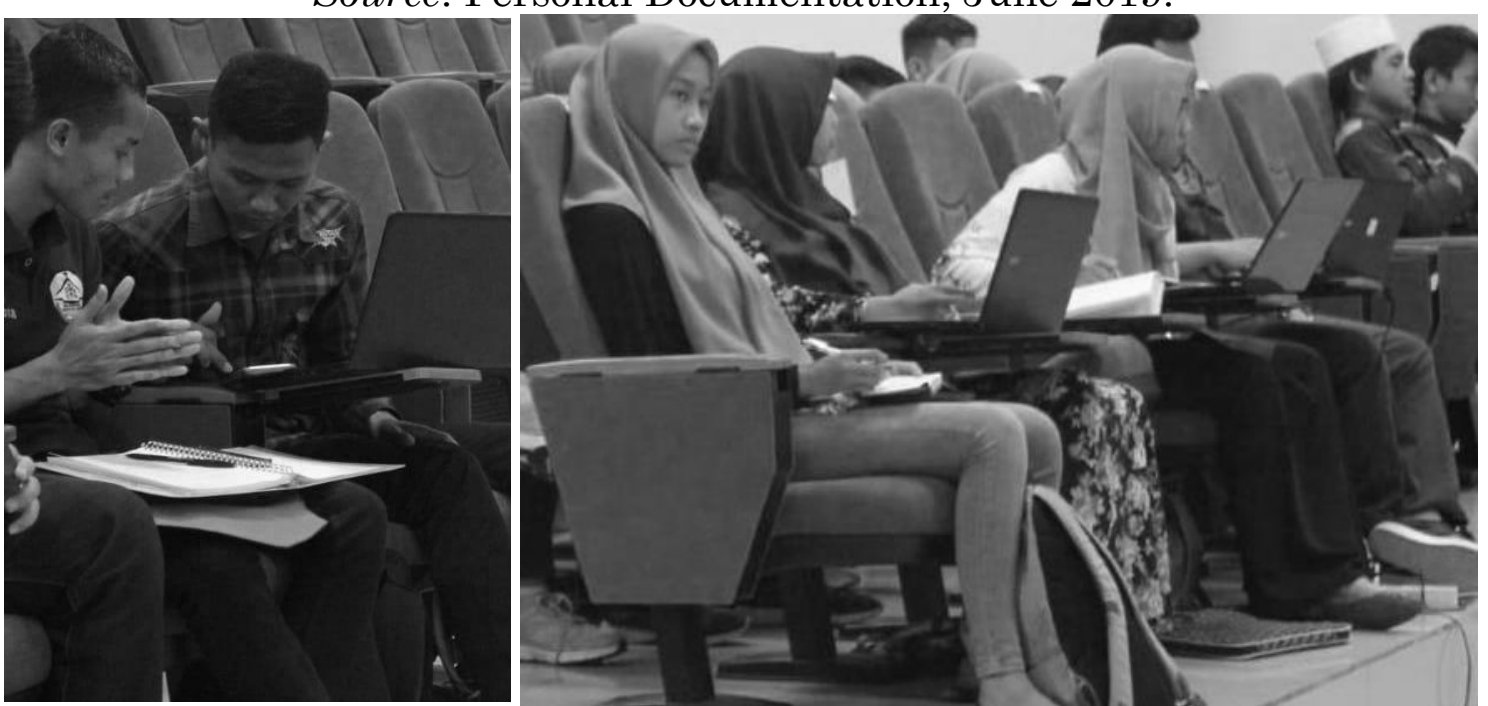

Figure 3 (left) and Figure 4 (right). Activity Participants are having a discussion. Source: Personal Documentation, June 2019

As for this activity, the stages are introduced to the activity participants about writing, as illustrated in Figure 5 below.

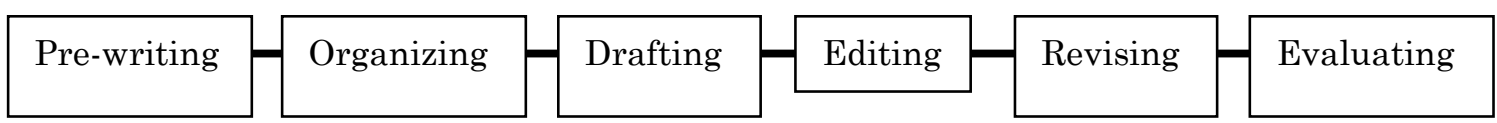

Figure 5. Academic writing steps 


\section{Strengthening the Literacy Capacity of Student Activists}

Literacy is as an ability to read and write. We know him by literacy or literacy. But now literacy has a broad meaning, so literacy is no longer single meaning but contains a variety of meanings (multi literacies). There are various literacy or literacy, for example computer literacy, media literacy, technology literacy, economic literacy, information literacy, and even moral literacy literacy). So, literacy or literacy can be interpreted as technology literacy, information literacy, critical thinking, sensitive to the environment, even sensitive to politics. A person is said to be literate if he is able to understand something because he reads the right information and does something based on his understanding of the contents of the reading (Herawati, 2017).

Yamin (2018) emphasized that literacy is a necessity that must be possessed by the education community, including students in it. In fact, it was underlined that literacy as an inseparable part of capital strengthening Human Resources (HR) in tertiary institutions becomes an important thing that must be done. Literacy is generally synonymous with reading and writing activities. Based on the Prague Declaration in 2003, literacy also includes the ability of a person to communicate in a meaningful community of praxis for social relations related to knowledge, language, and culture (UNESCO, 2003). Thus, literacy is in principle an inseparable part of the efforts to develop human resources who have the competence to strengthen in any case. The more knowledge that is obtained, accessed, and used as capital in self-development, this can encourage a movement to develop quality human resources. Literacy that is connected with capital in human development in the context of tertiary institutions is that the literacy ability of lecturers is their own capital for reviving scientific activities and culture. One manifestation of the program is writing competence called scientific publications.

The process of strengthening the literacy capacity of student activists in the community service program emphasizes ongoing assistance for participants. Activities are not only done once, but several times and focus on writing articles in the field of law for a particular journal.

The activities carried out by way of discussion together to explore ideas and critical thinking, also to provide a new and current understanding of legal issues. Discussions are also conducted in groups, and carried out in large numbers, and also small (divided into groups based on the same field of study). This activity was carried out on Monday-Wednesday (24-26 June 2019) at 14.00 until 15.30 WIB at the Faculty of Law, Semarang State University. Documentation of the activities can be seen as shown below. 


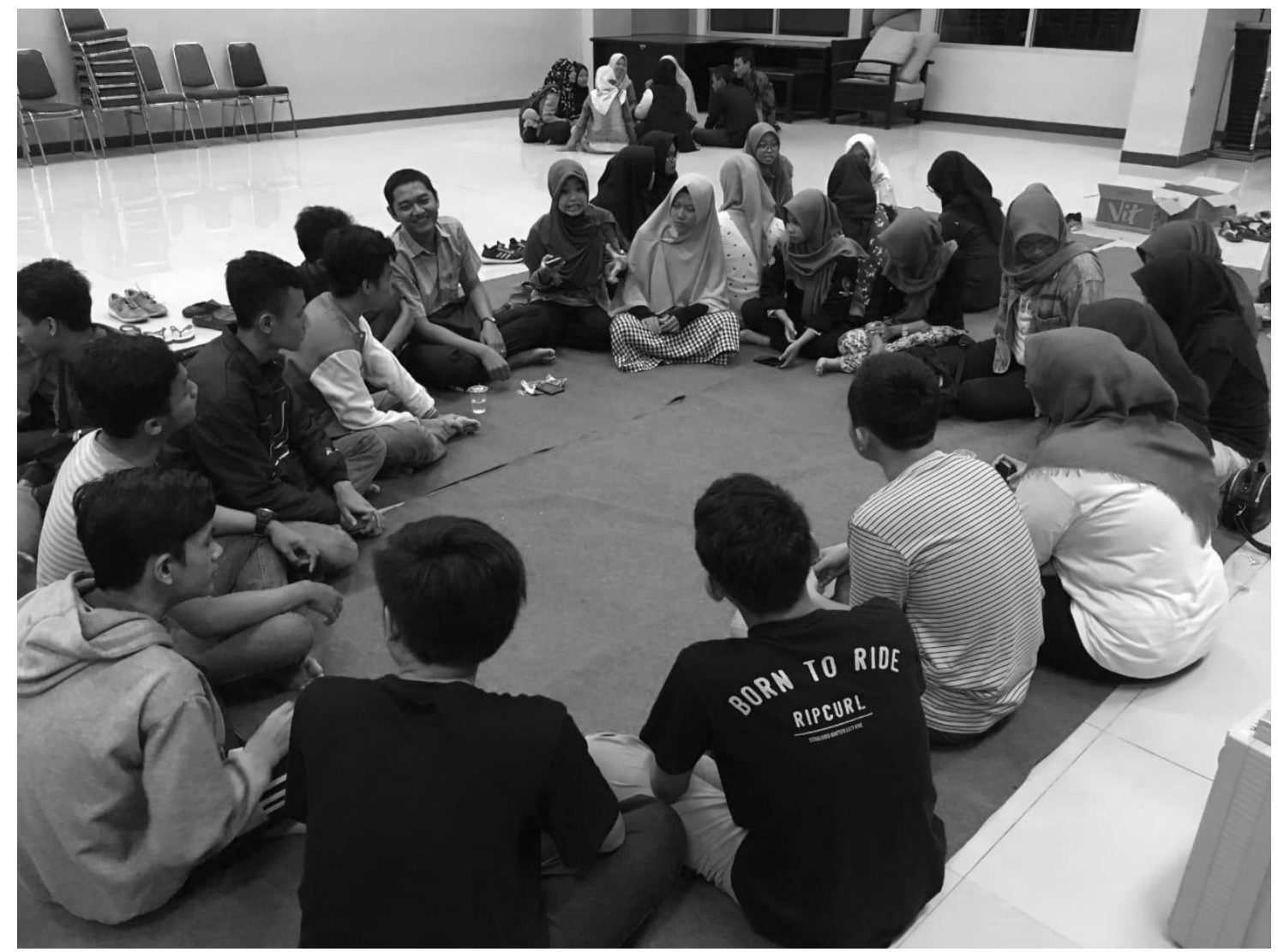

Figure 6. Participant discussion activities in large numbers. Source: personal documentation, June 2019

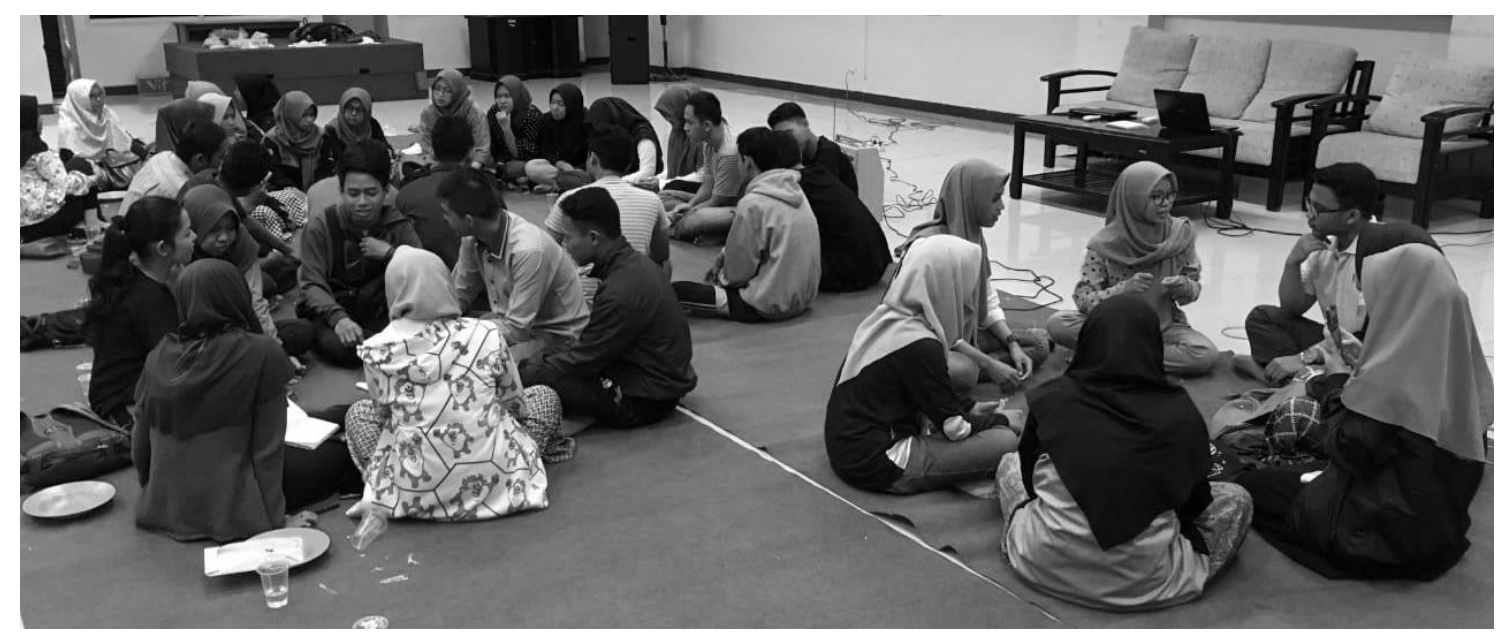

Figure 7. Participant discussion activities in small numbers (divided by groups according to the field of study). Source: personal documentation, 2019

\section{Scientific Journal Writing Assistance for Student Activists}

At this stage, program participants are immediately directed to make writing which will be sent to certain journals. The initial data of the participant's article title can be seen in the following table. 
Table 5 Initial Data Title of Writing Participants

\begin{tabular}{|c|c|c|}
\hline No & Name of Student & $\begin{array}{l}\text { Title of Article (in Bahasa, in } \\
\text { English) }\end{array}$ \\
\hline 1 & Aisyah Dara Pamungkas & $\begin{array}{l}\text { Mempertahankan Integritas dalam } \\
\text { Negeri Demokrasi di Balik Isu } \\
\text { Kampanye Negatif dan Kampanye } \\
\text { Hitam Jelang Pilpres } 2019\end{array}$ \\
\hline 2 & Angeline Melenia & $\begin{array}{l}\text { Kebijakan Hukuman Pidana Mati untuk } \\
\text { Menanggulangi Tindak Pidana } \\
\text { Narkotika di Indonesia }\end{array}$ \\
\hline 3 & $\begin{array}{l}\text { Anggie Rizqita Herda } \\
\text { Putri }\end{array}$ & $\begin{array}{l}\text { Perlindungan Hukum Bagi Korban } \\
\text { Tindak Pidana Perdagangan Orang di } \\
\text { Indonesia }\end{array}$ \\
\hline 4 & Arsita Dewi Fatasya & $\begin{array}{l}\text { Pembunuhan Berencana dalam } \\
\text { Prespektif Hak Asasi Manusia Dan } \\
\text { Kajian Viktimologi }\end{array}$ \\
\hline 5 & $\begin{array}{l}\text { Alycia Sandra Dinar } \\
\text { Andhini }\end{array}$ & $\begin{array}{l}\text { Perlindungan Hukum Dalam Kajian } \\
\text { Viktimologi Terkait Dengan Kekerasan } \\
\text { Terhadap Anak }\end{array}$ \\
\hline 6 & Ayu Setyaningrum & $\begin{array}{l}\text { Analisis Upaya Perlindungan Dan } \\
\text { Pemulihan Terhadap Korban Kekerasan } \\
\text { dalam Rumah Tangga Khususnya Anak- } \\
\text { Anak Dan Perempuan }\end{array}$ \\
\hline 7 & Azman Khoerul Muta'adi & $\begin{array}{l}\text { Citra Hukum Masa Kini: Berbagai } \\
\text { Permasalahan Hukum di Indonesia }\end{array}$ \\
\hline 8 & Dasri & $\begin{array}{l}\text { Penegakan Hukum Terpadu } \\
\text { (Gakkumdu) Dalam Penyelenggaraan } \\
\text { Pemilihan Umum di Indonesia }\end{array}$ \\
\hline 9 & Dwi Suci Mentari & $\begin{array}{l}\text { Kajian Hukum Tentang Tindak } \\
\text { Kekerasan Seksual Terhadap Anak Di } \\
\text { Indonesia }\end{array}$ \\
\hline 10 & $\begin{array}{l}\text { Fairuz Rhamdhatul } \\
\text { Muthia }\end{array}$ & $\begin{array}{l}\text { Kajian Hukum Tindak Pidana Pada } \\
\text { Kasus Kejahatan Dunia Maya Atau } \\
\text { Cybercrime Dalam Perkara Pencemaran } \\
\text { Nama Baik }\end{array}$ \\
\hline 11 & Ifan Dwi Chandra & $\begin{array}{l}\text { Politik Uang Sebagai Awal Munculnya } \\
\text { Tindak Korupsi Dalam Pilkada }\end{array}$ \\
\hline 12 & Kania Dewi Andhika Putri & $\begin{array}{l}\text { Pertanggungjawaban Keadilan dan } \\
\text { Kepastian di dalam Hukum }\end{array}$ \\
\hline 13 & Kresna Adi Prasetyo & Analisis Hukum Pidana Mengenai \\
\hline
\end{tabular}




\begin{tabular}{|c|c|c|}
\hline & & $\begin{array}{l}\text { Tindak Pidana Penistaan Agama Di } \\
\text { Indonesia }\end{array}$ \\
\hline 14 & Lita Hapsari & $\begin{array}{l}\text { Tinjauan Teoritis Cybercrime Case } \\
\text { Mengenai Penyebaran Hoax } \\
\text { di Media Sosial dan Sanksi Pidananya }\end{array}$ \\
\hline 15 & Melani Diah Sekar Puri & $\begin{array}{l}\text { Eksistensi Hukum Pidana Adat dan } \\
\text { Hukum Perdata Adat dalam } \\
\text { Perkembang-an Hukum Nasional } \\
\text { Indonesia }\end{array}$ \\
\hline 16 & $\begin{array}{l}\text { Melani Pratika } \\
\text { Yudaningrum }\end{array}$ & $\begin{array}{l}\text { Korupsi dan Hak Asasi Manusia } \\
\text { (Analisis Atas Dampak HAM Pada } \\
\text { Kasus-Kasus Tindak Pidana Korupsi Di } \\
\text { Indonesia) }\end{array}$ \\
\hline 17 & Miftakhul Ihwan & $\begin{array}{l}\text { Kerjasama Polisi Dan Pemerintah } \\
\text { Daerah Dalam Menegakkan Hukum } \\
\text { Dimasyarakat Sebagai Wujud } \\
\text { Keikutsertaan Dalam Menjaga } \\
\text { Keamanan Dan Ketertiban Masyarakat }\end{array}$ \\
\hline 18 & Nasichatus Sholechah & $\begin{array}{l}\text { Tindak Pidana Terorisme Dilihat dari } \\
\text { Sudut Hukum Materiil (Diatur di dalam } \\
\text { UU No. } 15 \text { Tahun 2003) }\end{array}$ \\
\hline 19 & Noviana Dwi Utami & $\begin{array}{l}\text { Jalan Tanpa Ujung, Korupsi Yang Tidak } \\
\text { Bertepi Dan Menjadi Penyakit Pejabat } \\
\text { Negeri }\end{array}$ \\
\hline 20 & Nur Rika Fitaloka & $\begin{array}{l}\text { Perlindungan Hukum Kepada Hak Anak } \\
\text { Angkat dalam Memperoleh Status } \\
\text { Hukum dengan Melalui Pencatatan } \\
\text { Hukum Pengangkatan Anak (Jika } \\
\text { Ditinjau dalam perspektif Hak Asasi } \\
\text { Manusia) }\end{array}$ \\
\hline 21 & Resa Nabila Ramadani & $\begin{array}{l}\text { Hubungan Body Shaming Terhadap } \\
\text { Penampilan Fisik Seseorang Dan } \\
\text { Penegakan Hukum Untuk Pelaku Body } \\
\text { Shaming }\end{array}$ \\
\hline 22 & Ria Juliana & $\begin{array}{l}\text { Perlindungan Hukum Terhadap Anak Di } \\
\text { Indonesia Sebagai Pelaku Dan Korban } \\
\text { Tindak Pidana }\end{array}$ \\
\hline 23 & Rizha Fanditya Ningtyas & $\begin{array}{l}\text { Tarik Ulur Penegakan Hukum UU ITE } \\
\text { (Cyberlaw) Di Indonesia (Analisis Kasus- } \\
\text { Kasus Kontroversial) }\end{array}$ \\
\hline
\end{tabular}




\begin{tabular}{|c|c|c|}
\hline 24 & Saktiani Nurul Hidayah & $\begin{array}{l}\text { Implementasi Pemilu dalam } \\
\text { Berdemokrasi di Indonesia }\end{array}$ \\
\hline 25 & Septi Sabela & $\begin{array}{l}\text { Hak Politik Mantan Narapidana } \\
\text { Korupsi (Studi Atas Wacana } \\
\text { Pembatasan Hak Politik Narapidana } \\
\text { Korupsi Di Indonesia }\end{array}$ \\
\hline 26 & Siti Nurmala & $\begin{array}{l}\text { Problematika Penegakan HAM di } \\
\text { Indonesia }\end{array}$ \\
\hline 27 & Siti Zanatya Katriantoro & $\begin{array}{l}\text { Kampanye Negatif dan Kampanye } \\
\text { Hitam dalam Konteks Demokrasi dan } \\
\text { Negara Hukum Indonesia }\end{array}$ \\
\hline 28 & Thera Retno Aprilia & $\begin{array}{l}\text { Politik Uang Dalam Demokrasi di } \\
\text { Indonesia }\end{array}$ \\
\hline 29 & Karin Aulia Rahmadhanty & $\begin{array}{l}\text { Hak Anak Angkat dalam Mendapatkan } \\
\text { Warisan Ditinjau dari Hukum Waris } \\
\text { Indonesia }\end{array}$ \\
\hline 30 & Dewi Ayu Pranesti & $\begin{array}{l}\text { Perlindungan Korban Dalam Kasus } \\
\text { Penyebaran Berita Hoax Di Media Sosial } \\
\text { Di Indonesia }\end{array}$ \\
\hline 31 & Ana Latifatul Muntamah & $\begin{array}{l}\text { Pernikahan Dini Di Indonesia: Faktor } \\
\text { Dan Peran Pemerintah (Perspektif } \\
\text { Penegakan Dan Perlindungan Hukum } \\
\text { Bagi Anak) }\end{array}$ \\
\hline 32 & Arsitas Dewi Fatasya & $\begin{array}{l}\text { Kajian Hukum Atas Pembunuhan } \\
\text { Berencana Yang Disertai Penganiyaan } \\
\text { Dan Mutilasi (Studi Atas Kasus-Kasus } \\
\text { Mutilasi Kontroversi Di Indonesia) }\end{array}$ \\
\hline 33 & Kaifa Nur Hanifa & $\begin{array}{l}\text { Perlindungan Hak Asasi Manusia Bagi } \\
\text { Tenaga Kerja Kontrak Di Indonesia } \\
\text { (Human Rights Protection For Labor } \\
\text { Contracts In Indonesia) }\end{array}$ \\
\hline 34 & Yudha Chandra Arwana & $\begin{array}{l}\text { Jalur Mediasi dalam Penyelesaian } \\
\text { Sengketa Pertanahan Sebagai Dorongan } \\
\text { Pemenuhan Hak Asasi Manusia }\end{array}$ \\
\hline 35 & $\begin{array}{l}\text { Anggie Rizqita Herda } \\
\text { Putri }\end{array}$ & $\begin{array}{l}\text { Perlindungan Hukum Bagi Korban } \\
\text { Tindak Pidana Perdagangan Orang Di } \\
\text { Indonesia }\end{array}$ \\
\hline
\end{tabular}

Furthermore, all participants receive intensive periodic assistance. The assistance is done in two ways, namely: (1) face to face (offline), and (2) 
online. Face-to-face mentoring is carried out to explore and explore ideas from participants and guide participants. While online methods are used to increase the intensity of the discussion regarding the development of the progress of the article made.

Through table 5 it can be seen that the participants' titles have led to a particular focus of the case or theme, although there are several titles whose scope is still quite broad. In order to sharpen the title of the article, participants were stimulated by various questions and discussions to draw ideas from the participants so that a proper title was formed to be published in a scientific article.

Assistance does not only stop at the title, but until an article is completed (conclusions and bibliography). Participants were also accompanied by the method of quoting and retrieving data, so that the articles written were more weighty.

Based on the results of the assistance, at least obtained articles have been submitted to various legal scientific journals in Indonesia, and have been published as data in Table 6 .

Table 6 Published Articles of Participant

\begin{tabular}{|c|c|c|c|}
\hline No & $\begin{array}{l}\text { Name of } \\
\text { Student }\end{array}$ & $\begin{array}{l}\text { Title of Article (in } \\
\text { Bahasa, in English) }\end{array}$ & $\begin{array}{l}\text { Publisher, } \\
\text { Journal }\end{array}$ \\
\hline 1 & $\begin{array}{l}\text { Kania Dewi } \\
\text { Andhika Putri }\end{array}$ & $\begin{array}{l}\text { Tinjauan Teoritis Keadilan } \\
\text { Dan Kepastian Dalam } \\
\text { Hukum Di Indonesia (The } \\
\text { Theoretical Review of } \\
\text { Justice And Legal } \\
\text { Certainty In Indonesia) }\end{array}$ & $\begin{array}{l}\text { Mimbar Yustitia } 2 \\
(2), 142-158,2018\end{array}$ \\
\hline 2 & $\begin{array}{l}\text { Ayu } \\
\text { Setyaningrum }\end{array}$ & $\begin{array}{l}\text { Analisis Upaya } \\
\text { Perlindungan Dan } \\
\text { Pemulihan Terhadap } \\
\text { Korban Kekerasan Dalam } \\
\text { Rumah Tangga (Kdrt) } \\
\text { Khususnya Anak-Anak } \\
\text { Dan Perempuan }\end{array}$ & $\begin{array}{l}\text { Jurnal } \\
\text { Muqoddimah: } \\
\text { Jurnal Ilmu Sosial, } \\
\text { Politik Dan } \\
\text { Hummaniora } 3 \text { (1), } \\
\text { 9-19, } 2019\end{array}$ \\
\hline 3 & Ria Juliana & $\begin{array}{l}\text { Anak Dan Kejahatan } \\
\text { (Faktor Penyebab Dan } \\
\text { Perlindungan Hukum) }\end{array}$ & $\begin{array}{l}\text { Jurnal Selat } 6(2) \text {, } \\
225-234,2019\end{array}$ \\
\hline 4 & LE Lestari & $\begin{array}{l}\text { Penegakan Dan } \\
\text { Perlindungan Hak Asasi } \\
\text { Manusia Di Indonesia }\end{array}$ & $\begin{array}{l}\text { Jurnal Komunikasi } \\
\text { Hukum (Jkh) } 5 \text { (2), } \\
12-25,2019\end{array}$ \\
\hline
\end{tabular}




\begin{tabular}{|c|c|c|c|}
\hline & & $\begin{array}{l}\text { Dalam Konteks } \\
\text { Implementasi Sila } \\
\text { Kemanusiaan Yang Adil } \\
\text { Dan Beradab }\end{array}$ & \\
\hline 5 & $\begin{array}{l}\text { Anggie Rizqita } \\
\text { Herda Putri }\end{array}$ & $\begin{array}{l}\text { Perlindungan Hukum Bagi } \\
\text { Korban Tindak Pidana } \\
\text { Perdagangan Orang Di } \\
\text { Indonesia (Legal Protection } \\
\text { For Victims Of Human } \\
\text { Trafficking Crimes In } \\
\text { Indonesia) }\end{array}$ & $\begin{array}{l}\text { Res Judicata } 2 \text { (1), } \\
170-185,2019\end{array}$ \\
\hline 6 & $\begin{array}{l}\text { Yudha Chandra } \\
\text { Arwana }\end{array}$ & $\begin{array}{l}\text { Jalur Mediasi Dalam } \\
\text { Penyelesaian Sengketa } \\
\text { Pertanahan Sebagai } \\
\text { Dorongan Pemenuhan Hak } \\
\text { Asasi Manusia }\end{array}$ & $\begin{array}{l}\text { Jambura Law } \\
\text { Review } 1(2), 212- \\
236,2019\end{array}$ \\
\hline 7 & $\begin{array}{l}\text { Aisyah Dara } \\
\text { Pamungkas }\end{array}$ & $\begin{array}{l}\text { Demokrasi Dan Kampanye } \\
\text { Hitam Dalam } \\
\text { Penyelenggaraan } \\
\text { Pemilihan Umum Di } \\
\text { Indonesia (Analisis Atas } \\
\text { Black Campaign Dan } \\
\text { Negative Campaign) }\end{array}$ & $\begin{array}{l}\text { Diktum: Jurnal } \\
\text { Syariah Dan Hukum } \\
17 \text { (1), 16-30, } 2019\end{array}$ \\
\hline 8 & $\begin{array}{l}\text { Wiki Oktama } \\
\text { Putri }\end{array}$ & $\begin{array}{l}\text { Penegakan Hukum } \\
\text { Terhadap Anggota } \\
\text { Legislatif Dalam Kasus } \\
\text { Tindak Pidana Korupsi Di } \\
\text { Indonesia }\end{array}$ & $\begin{array}{l}\text { Al Daulah: Jurnal } \\
\text { Hukum Pidana Dan } \\
\text { Ketatanegaraan } 8 \\
(1), 1-15,2019\end{array}$ \\
\hline 9 & EM Saputri & $\begin{array}{l}\text { Perlindungan Hukum } \\
\text { Terhadap Konsumen } \\
\text { Dalam Hal Pengembang } \\
\text { (Developer) Apartemen } \\
\text { Dinyatakan Pailit }\end{array}$ & $\begin{array}{l}\text { Jurnal Hukum } \\
\text { Bisnis Bonum } \\
\text { Commune } 2(2), 151 \text { - } \\
161,2019\end{array}$ \\
\hline 10 & ASD Andhini & $\begin{array}{l}\text { Analisis Perlindungan } \\
\text { Hukum Terhadap Tindak } \\
\text { Kekerasan Pada Anak Di } \\
\text { Indonesia }\end{array}$ & $\begin{array}{l}\text { Ajudikasi: Jurnal } \\
\text { Ilmu Hukum } 3 \text { (1), } \\
41-52,2019\end{array}$ \\
\hline 11 & MDS Puri & $\begin{array}{l}\text { Pengaruh Adat Dalam } \\
\text { Hukum Keluarga Terhadap } \\
\text { Pembaruan Hukum }\end{array}$ & $\begin{array}{l}\text { Volksgeist: Jurnal } \\
\text { Ilmu Hukum Dan } \\
\text { Konstitusi } 2 \text { (1), } 73 \text { - }\end{array}$ \\
\hline
\end{tabular}




\begin{tabular}{|c|c|c|c|}
\hline & & Nasional & 87,2019 \\
\hline 12 & NB Setyawan & $\begin{array}{l}\text { Analisis Perlindungan } \\
\text { Terhadap Toleransi } \\
\text { Kebebasan Beragama Di } \\
\text { Indonesia Dalam } \\
\text { Perspektif Hak Asasi } \\
\text { Manusia }\end{array}$ & $\begin{array}{l}\text { Nurani: Jurnal } \\
\text { Kajian Syari'ah Dan } \\
\text { Masyarakat 19 (1), } \\
27-34,2019\end{array}$ \\
\hline 13 & RMA Ilyasa & $\begin{array}{l}\text { Transaksi Bitcoin Dalam } \\
\text { Perspektif Hukum Islam } \\
\text { Dan Hukum Positif } \\
\text { Indonesia }\end{array}$ & $\begin{array}{l}\text { Mahkamah: Jurnal } \\
\text { Kajian Hukum } \\
\text { Islam } 4 \text { (1), 26-35, } \\
2019\end{array}$ \\
\hline 14 & SA Choirinnisa & $\begin{array}{l}\text { Pertanggungjawaban } \\
\text { Korporasi Dalam Tindak } \\
\text { Pidana Pencucian Uang } \\
\text { Dalam Prinsip Hukum } \\
\text { Pidana Indonesia }\end{array}$ & $\begin{array}{l}\text { Jurnal Mercatoria } \\
12(1), 43-53,2019\end{array}$ \\
\hline 15 & NM Lubis & $\begin{array}{l}\text { Criminal Liability For } \\
\text { Witnesses Giving Fake } \\
\text { Testimony Under The Oath } \\
\text { In The Trial }\end{array}$ & $\begin{array}{l}\text { Morality: Jurnal } \\
\text { Ilmu Hukum } 5 \text { (1), } \\
\text { 1-13, } 2019\end{array}$ \\
\hline 16 & DA Pranesti & $\begin{array}{l}\text { Perlindungan Korban } \\
\text { Dalam Kasus Penyebaran } \\
\text { Berita Hoax Di Media } \\
\text { Sosial Di Indonesia }\end{array}$ & $\begin{array}{l}\text { Jurnal Hukum } \\
\text { Media Bhakti } 3 \text { (1), } \\
8-17,2019\end{array}$ \\
\hline 17 & FR Muthia & $\begin{array}{l}\text { Kajian Hukum Pidana } \\
\text { Pada Kasus Kejahatan } \\
\text { Mayantara (Cybercrime) } \\
\text { Dalam Perkara } \\
\text { Pencemaran Nama Baik Di } \\
\text { Indonesia }\end{array}$ & $\begin{array}{l}\text { Resam Jurnal } \\
\text { Hukum } 5 \text { (1), 21-39, } \\
2019\end{array}$ \\
\hline 18 & MA Nurdiana & $\begin{array}{l}\text { Tindak Pidana } \\
\text { Pemerkosaan: Realitas } \\
\text { Kasus Dan Penegakan } \\
\text { Hukumnya Di Indonesia } \\
\text { (Crime Of Rape: Case } \\
\text { Reality And Law } \\
\text { Enforcement In Indonesia) }\end{array}$ & $\begin{array}{l}\text { Literasi Hukum } 3 \\
(1), 52-63,2019\end{array}$ \\
\hline 19 & KA Prasetyo & $\begin{array}{l}\text { Analisis Hukum Pidana } \\
\text { Mengenai Tindak Pidana } \\
\text { Penistaan Agama Di } \\
\end{array}$ & $\begin{array}{l}\text { Gorontalo Law } \\
\text { Review } 2 \text { (1), 1-12, } \\
2019\end{array}$ \\
\hline
\end{tabular}




\begin{tabular}{|c|c|c|c|}
\hline & & Indonesia & \\
\hline 20 & AL Muntamah & $\begin{array}{l}\text { Pernikahan Dini Di } \\
\text { Indonesia: Faktor Dan } \\
\text { Peran Pemerintah } \\
\text { (Perspektif Penegakan Dan } \\
\text { Perlindungan Hukum Bagi } \\
\text { Anak) }\end{array}$ & $\begin{array}{l}\text { Widya Yuridika } 2 \\
(1), 1-12,2019\end{array}$ \\
\hline 21 & J Fitriyaningrum & $\begin{array}{l}\text { The Regulatory Model For } \\
\text { Eradication Corruption In } \\
\text { Infrastructure Funding }\end{array}$ & $\begin{array}{l}\text { Varia Justicia } 15 \text { (1), } \\
36-42,2019\end{array}$ \\
\hline 22 & MBK Dewi & $\begin{array}{l}\text { Emancipation And Legal } \\
\text { Justice; Portrait Of } \\
\text { Women's Legal Protection } \\
\text { In Indonesia }\end{array}$ & $\begin{array}{l}\text { Jurnal Cita Hukum } \\
7(1), 2019\end{array}$ \\
\hline 23 & A Angga & $\begin{array}{l}\text { Penerapan Bantuan } \\
\text { Hukum Bagi Masyarakat } \\
\text { Kurang Mampu Di } \\
\text { Indonesia }\end{array}$ & $\begin{array}{l}\text { Diversi: Jurnal } \\
\text { Hukum } 4(2), 218- \\
236,2019\end{array}$ \\
\hline 24 & A Setyaningrum & $\begin{array}{l}\text { Analisis Upaya } \\
\text { Perlindungan Dan } \\
\text { Pemulihan Terhadap } \\
\text { Korban Kekerasan Dalam } \\
\text { Rumah Tangga (Kdrt) } \\
\text { Khususnya Anak-Anak } \\
\text { Dan Perempuan }\end{array}$ & $\begin{array}{l}\text { Jurnal } \\
\text { Muqoddimah: } \\
\text { Jurnal Ilmu Sosial, } \\
\text { Politik Dan } \\
\text { Hummaniora } 3 \text { (1), } \\
\text { 9-19, } 2019\end{array}$ \\
\hline 25 & AD Fatasya & $\begin{array}{l}\text { Kajian Hukum Atas } \\
\text { Pembunuhan Berencana } \\
\text { Yang Disertai Penganiyaan } \\
\text { Dan Mutilasi (Studi Atas } \\
\text { Kasus-Kasus Mutilasi } \\
\text { Kontroversi Di Indonesia) }\end{array}$ & $\begin{array}{l}\text { Jurnal Ilmu Hukum: } \\
\text { Fakultas Hukum } \\
\text { Universitas Riau } 8 \\
(1), 118-144,2019\end{array}$ \\
\hline 26 & Wandi Arifin & $\begin{array}{l}\text { Asas Keadilan Upah Guru } \\
\text { Honorer Dalam Perspektif } \\
\text { Hukum (Principle Of } \\
\text { Justice For Honorary } \\
\text { Teacher Wages In A Legal } \\
\text { Perspective) }\end{array}$ & $\begin{array}{l}\text { Riau Law Journal } 3 \\
(1), 85-104,2019\end{array}$ \\
\hline
\end{tabular}

All of these articles have also been indexed by Google Scholars so that they are listed in national and international scientific journal databases. In 
addition, all articles that have been published can be accessed free of charge through the open journal system on each journal page.

\section{Conclusion}

Literacy culture among student activists is still relatively low, however, stimulus through ongoing publications is one way to increase the academic writing capacity and critical thinking of student activists. The program concludes that publication assistance for students can be done in stages, periodically, and continuously. Exploring the ideas of law students is very important, especially in analyzing contemporary issues. The introduction of a publication system of all kinds seems to be an active student in making publications in many media.

Based on the program that has been implemented, the team suggested that the need for a policy formulation related to student publications. In addition, intensive publication assistance is needed, especially in small groups (limited participants) and using targets and commitment agreements, so students are encouraged to do publication targets to enhance critical thinking as activists of law students.

\section{E. Acknowledgments}

Authors would like to thank to Dean Faculty of Law Universitas Negeri Semarang, to Research and Community Services Unit Faculty of Law UNNES, Law Students Organization and Union Faculty of Law UNNES, and all parties involved on this community services program and this research. The research and community services program is funded by Faculty of Law Universitas Negeri Semarang

\section{F. Declaration of Conflicting Interests}

The authors state that there is no potential conflict of interest in the research, authorship, and / or publication / publication of this article.

\section{G. Funding}

Program of the community services and research funded by Faculty of Law, Universitas Negeri Semarang on scheme of Grants for Community Service Program for Lecturers of 2019. 


\section{H. References}

Anwar, K. (2012). Tidak Semata IPK, Tidak Sebatas Wisuda: Memahami Dinamika Motivasi Berprestasi Akademik Mahasiswa Aktivis. Skripsi. Yogyakarta: Universitas Gadjah Mada.

Anonim. (2018). Tanggapan Rektor Unnes soal Demo Mahasiswa yang Berujung Ricuh. Liputan 6 edition 8 June, retrieved from https://www.liputan6.com/regional/read/3554192/tanggapan-rektorunnes-soal-demo-mahasiswa-yang-berujung-ricuh

Barr, F. D., \& Harta, I. (2016). 'Analisis Manajemen Waktu Organisasi dan Kuliah Aktivis Mahasiswa Program Studi Pendidikan Matematika Universitas Muhammadiyah Surakarta'. PRISMA, Prosiding Seminar Nasional Matematika, IX(1), 280-285. retrieved from https://journal.unnes.ac.id/sju/index.php/prisma/article/view/21484

Budi, T. (2018). Demo Mahasiswa Universitas Negeri Semarang Tolak Uang Pangkal Berujung Rusuh. OKEZONE edition 7 June, retrieved from https://news.okezone.com/read/2018/06/07/512/1908011/demomahasiswa-universitas-negeri-semarang-tolak-uang-pangkalberujung-rusuh

DiPipi-Hoy, C., Jitendra, A. K., \& Kern, L. (2009). 'Effects of Time Management Instruction on Adolescents Ability to Self-Manage Time in a Vocational Setting'. The Journal of Special Education, 43(3), 145159.

Feist, J. \& Feist, G.J. (2010). Teori Kepribadian. Jakarta: Salemba Humanika.

Herawati, L. (2017). 'Budaya Literasi Media dalam Meningkatkan Daya Baca Mahasiswa IAIN Cirebon'. Paedagogia: Jurnal Pendidikan, 6(2), 294-309.

Septiani, P. (2016). 'Orientasi Karakter Perilaku Aktivis Mahasiswa (Character Orientation of Students Activist Behavior)'. Jurnal Riset Mahasiswa Bimbingan dan Konseling, 5(12), 636-646. retrieved from http://journal.student.uny.ac.id/ojs/index.php/fipbk/article/viewFile/62 $\underline{48 / 6000}$

Oley, P.C. (2013). 'Perilaku Politik Aktivis Mahasiswa Fakultas Ilmu Sosial dan Ilmu Politik Universitas Sam Ratulangi (Suatu Studi Terhadap Pengurus Organisasi Mahasiswa Fakultas Ilmu Sosial dan Ilmu Politik Universitas Sam Ratulangi Tahun 2012)'. Jurnal Politico, 1(3), 31-41. retrieved from https://ejournal.unsrat.ac.id/index.php/politico/article/view/2514/2050

Pranoto, N. (2010). 'Sekilas Academic Writing: Proses dan Permasalahannya (Bagian 1)'. Online, edition 15 March 2010, 
retrieved from https://rayakultura.net/sekilas-academicwritingproses-dan-permasalahannyal

Susan, N. (2009). Sosiologi Konflik dan Isu-isu Konflik Kontemporer. Jakarta: Kencana Prenada Media Group.

Sugiyarto. (2018). Demo Mahasiswa Unnes Menolak Uang Pangkal Dilanjutkan Menginap di Depan Rektorat. TRIBUNNEWS edition 5 June, retrieved from http://www.tribunnews.com/regional/2018/06/05/demo-mahasiswaunnes-menolak-uang-pangkal-dilanjutkan-menginap-di-depanrektorat

Lestari, S., \& Chasanatun, T.W. (2016). 'Analisis Kompetensi dan Permasalahandalam Menulis Artikel Pada Mata Kuliah Academic Writing'. Jurnal LPPM, 4(1), 76-84.

Tawakal, I. (2015). Kritis Pada Diri Mahasiswa, Untuk Perubahan. Kompasiana, edition 15 June, retrieved from https://www.kompasiana.com/tautawtau/550b3ec3a33311b0142e39e1/ kritis-pada-diri-mahasiswa-untuk-perubahan

Wae, W. (2014). Membangun Sikap Kritis. Opini Online OKEZONE, edition 1 December, retrieved from https://news.okezone.com/read/2014/12/01/65/1072809/membangunsikap-kritis

Widiarto, A. (2018). Ratusan Mahasiswa Unnes Demo Tolak Uang Pangkal. Suara Merdeka, edition 4 June, retrieved from https://www.suaramerdeka.com/news/baca/92227/ratusanmahasiswa-unnes-demo-tolak-uang-pangkal

Wigati, F.A. (2014). 'Kesulitan Pada Aspek-Aspek Writing Mahasiswa dengan English Proficiency Levels yang Berbeda'. Jurnal Ilmiah Solusi, 1(3), 46-61.

Yamin, M. (2018). 'Kebijakan Literasi Untuk Meningkatkan Produktivitas Publikasi di Perguruan Tinggi'. Jurnal Analisis Sistem Pendidikan Tinggi, 2(1), 19-26. 


\author{
QuOTE
}

\title{
The important thing is not to stop questioning. Curiosity has its own reason for existing.
}

Albert Einstein 